\title{
EDUKACJA ZAWODOWA W KREOWANIU ZMIAN SZKOLNICTWA PONADGIMNAZJALNEGO I WYŻSZEGO, ZORIENTOWANYCH NA RYNEK PRACY
}

\begin{abstract}
Streszczenie: Edukacja zawodowa rozpoznana naukowo na przełomie XX i XXI wieku aktualnie wpisuje się w kierunki reform szkolnictwa ponadgimnazjalnego i wyższego i ich rynkowego orientowania, wyrażając w ten sposób troskę o losy zawodowe absolwentów, rozumiane jako ich szanse na zatrudnienie, czyli wpisanie edukacji w oczekiwania pracodawców. W ich wypełnieniu przydatne będą modele zawodów i ich kształcenia, w tym modułowego, dostosowywanego do efektów kształcenia na różnych jego poziomach i w różnych rozwiązaniach organizacyjnych, starających zapewniać się w ten sposób nie tylko elastyczność ścieżek, ale również adekwatność oferty edukacyjnej do nieustannie zmieniającego się świata pracy. Należy żywić nadzieję, iż powyższe rozwiązania, wdrażane do praktyki edukacyjnej po ponad dwudziestoletnich badaniach, poprawią relację między edukacją a rynkiem pracy, wyrażoną lepszą sytuacją absolwentów na tymże rynku.
\end{abstract}

Słowa kluczowe: edukacja, edukacja zawodowa, reforma oświaty, rynek pracy

\section{Wstęp}

Wciąż pogarszająca się sytuacja absolwentów, w tym szkół wyższych, na rynku pracy stanowi uzasadnienie podjętych rozważań w temacie, które będą starały się odpowiedzieć na poniższe pytania:

1. Na ile podejmowane działania w obszarze polityki oświatowej mogą poprawić sytuację absolwentów kształcenia zawodowego, w tym wyższego?

2. W jaki sposób próbuje zmieniać się szkolnictwo zawodowe, w tym wyższe, aby absolwenci czuli się partnerami w grze rynkowej o zatrudnienie?

W odpowiedzi na powyższe pytania przydatne staje się poszukiwanie modelu szkolnictwa zawodowego, poprzedzone analizą danych statystycznych, ściśle połączonych ze strukturami zawodów.

\section{Sytuacja absolwentów, w tym szkół wyższych, na rynku pracy - w poszukiwaniu kryterium reformy oświaty}

Celem podejmowania dalszej edukacji przez różne grupy absolwentów jest wiara w znalezienie atrakcyjnej i ciekawej pracy po jej zakończeniu. Tymczasem dane statystyczne już od przełomu XX i XXI wieku pokazują, że wzrostowi liczby absolwentów szkół wyższych 
towarzyszy wzrastający poziom bezrobocia, co pogarsza ogólną sytuację osób młodych na rynku pracy. Poddany szczegółowej analizie przez Cz. Plewkę okres miedzy 2005 a 2012 rokiem pokazuje, że o ile zmniejszyła się ogólna liczba osób bezrobotnych z 2773 tysięcy do 2137 tysięcy, to w odniesieniu do obywateli z wyższym wykształceniem, wystąpił wzrost osób pozostających bez pracy z 152 tysięcy do 251 tysięcy, co oznacza, że w tej grupie przybyło prawie 100 tysięcy osób pozostających bez pracy (Plewka 2013, s. 77-83). Tak dramatycznej sytuacji nie zanotował żaden poziom wykształcenia, bowiem w grupie ze średnim wykształceniem liczba osób pozostających bez pracy zmniejszyła się o prawie 134 tysięcy osób, a z wykształceniem zasadniczym zawodowym o prawie 300 tysięcy osób. W tonacji tej, czyli wzrastającego bezrobocia wśród młodych ludzi, a zatem obejmującego również absolwentów szkól wyższych, pozostają również wskaźniki w odniesieniu do wieku, z których wynika, że w grupie osób bezrobotnych prawie 47,1\% stanowi właśnie ta grupa społeczna, czyli osoby do 35 roku życia. Wśród niej znaczącą część stanowią absolwenci szkół wyższych lub osoby z wyższym wykształceniem o krótkim stażu pracy. W samym 2012 roku stanowiły one 15,4\% ogółu bezrobotnych ze stażem poniżej 1 roku, oraz 38,3\% ogółu bezrobotnych ze stażem poniżej 5 lat, utrzymując stałą tendencje w analizowanych latach, tj. 2005 - 2012 (Plewka 2013, s. 77-83).

Kolejnym problemem edukacji zawodowej pozostaje wciąż aktualny dysonans między oczekiwaniami tworzącego się rynku pracy a możliwościami poszczególnych typów szkół, o którym mówił już w 1997 roku Stefan M. Kwiatkowski, dowodząc potrzeby reformy kształcenia zawodowego, na wszystkich poziomach, w tym szkół wyższych i dalszych przewartościowań w strukturach zawodów wyznaczających treści orientujące (HejnickaBezwińska 1989) - zawodowo i na pracę -czyli kształcenie umożliwiające uzyskanie kwalifikacji akceptowanych przez rynek pracy (Strzelecki 2002). Do nich niewątpliwie należeć powinny zawody o charakterze usługowym, aby zatrudnieni w nich pracownicy mogli w przyszłości nadać społeczeństwu nowe oblicze, określonego mianem informacyjnego, a także umiejętności uniwersalne, określone mianem kluczowych, przydatne w rozwoju kompetencji społecznych (Kędzierska 2007), wpisujących się w element postaw zawodowych, które będą dopełnione treściami i umiejętnościami zawodowymi a opisywane są kategoriami efektów kształcenia (Ustawa $z$ dnia 11 lipca 2014 r. o zmianie ustawy - Prawo o szkolnictwie wyższym oraz niektórych innych ustaw, Dz. U. 2014 poz. 1198). Stanowić to będzie informację dla pracodawców o przydatności zatrudnienia danego pracownika. To wybrane główne uwarunkowania obecnej sytuacji absolwentów na rynku pracy, których los może poprawić już nie kształcenie zawodowe, ale edukacja zawodowa zorientowana na rynek pracy, co stanowi treść poniższych rozważań.

\section{Orientowanie edukacji zawodowej na kompetencje}

Problematyka orientowania edukacji na rynek pracy jest zagadnieniem bardzo złożonym, w co wpisuje się przybliżenie istoty edukacji zawodowej wraz z ukazaniem jej modelów, rynkowo skorelowanych ze strukturami zawodów objętych reformą oświaty. Punktem wyjścia rozważań jest edukacja, która wciąż pozostaje jednym z kluczowych pojęć pedagogiki. Ono wciąż pozostaje niedookreślone, gdyż jedni kojarzą go z wykształceniem (Doroszewski 1975), a inni z wychowaniem (Okoń 2001). Obecnie upowszechnia się szerokie rozumienie tego terminu jako ogółu procesów oświatowo-wychowawczych, obejmujących kształcenie 
i wychowanie oraz szeroko pojmowaną oświatę (Baraniak 2001, s. 112; 2008, s. 22; 2013, s. 180). Powyższy pogląd pozwala postrzegać edukację jako proces wielowarstwowy, odbywający się w większości środowisk towarzyszących rozwojowi człowieka, a mianowicie w rodzinie, szkole, pracy, a także we wszelkich instytucjach oraz organizacjach tzw. wyższej użyteczności. Edukacja jest więc procesem nieograniczonym, obejmującym ogół placówek i instytucji prowadzących działalność oświatową i wychowawczą, w których uczestniczy wielość podmiotów - bez względu na wiek, co umożliwia całożyciowy ich rozwój. Owo rozumienie edukacji legło u podstaw nowej działowej koncepcji pedagogiki pracy, wedle której kształcenie i wychowanie pozostając w integralnej łączności, pokazują że procesy pracy interesuje zarówno kształcenie skoncentrowane na umiejętnościach, nawykach i sprawnościach, jak i wychowanie zainteresowane kształtowaniem odpowiednich postaw, wyrażonych stosunkiem do pracy, jakością wytwarzanych wytworów itp. W ową koncepcję edukacji, osadzonej w paradygmacie pedagogiki pracy, wpisuje się pogląd na edukację Bogusława Śliwerskiego, który twierdzi, że „traktowana jest ona jako:

1. Proces permanentnego uczenia się człowieka przez całe życie.

2. Prawo, a zarazem obywatelska powinność człowieka oraz imperatywów społecznych.

3. Instrument władzy politycznej do realizacji określonych interesów i celów społecznych, partyjnych, związkowych, narodowych i kulturowych itp.

4. Obszar samoregulacji społecznej, główny czynnik rozwoju ludzkiego kapitału, jakości życia społeczeństwa czy cywilizacji.

5. Typ przemocy symbolicznej narzuconej kulturą grupy dominującej przedstawicielom innych grup społecznych, tym samym czynnik stratyfikacji społecznej, który generuje mechanizmy i szanse awansu społecznego oraz selekcji i marginalizacji.

6. «Ekran kultury» tłumaczący złożoność jej pola znaczeń i symboli.

7. Typ normatywnego dyskursu, przedstawiającego określoną perspektywę myślową umożliwiającą opowiedzenie się po jednej ze stron kontaktów światopoglądowych, ideologicznych czy moralnych" (Śliwerski 2003, s. 905).

Cytowany autor stwierdza, że wychowanie jest „z jednej strony [...] czynnikiem kształtowania tożsamości człowieka, a z drugiej zaś nieodzownym warunkiem twórczym jego naturalnego rozwoju" (Śliwerski 2003, s. 903), ukazującego użyteczność edukacji permanentnej (Wiatrowski 2004), w model której wpisana jest interesująca nas kategoria edukacji zawodowej, istotna dla pedagoga pracy. Ona sprowadza się nie tylko do opanowania wiedzy zawodowej opisanej wiadomościami, umiejętnościami, nawykami i sprawnościami zawodowymi, ale także kształtowania podstaw, poglądów, zainteresowań prozawodowych, myślenia koncepcyjnego, innowacyjnego, twórczego, a także stosunku do świata wartości, społeczeństwa, drugiego człowieka, samego siebie, świata kultury i przyrody. A zatem trzeba zgodzić się z poglądem, że celem współczesnej edukacji zawodowej jest kształtowanie pełni człowieczeństwa, „a nie wykonawcy określonych zadań, $w$ myśl holistycznej teorii urzeczywistniającej się $w$ czterowymiarowym modelu edukacji, uwzględniającej harmonijny rozwój fizyczny, intelektualny, społeczny $i$ duchowy istoty ludzkiej” (Łyko 1998, s. 143). Należy bowiem kształtować osobowość nie tylko zawodową, ale osobowość człowieka jako podmiotu edukacyjnego, co edukacji zawodowej nadaje wymiar humanistyczny (Turos 2006), a jej podmiot dzięki autokreacji „współformuje jednostki przez swe względne autonomiczne wybory i działania [...] przyjmowane z większym lub mniejszym udziałem własnym” (Pietrasiński 2009, s. 71). Dzięki temu 
dokonuje się rozwój człowieka inspirowany aktywnością, twórczymi możliwościami, które przenoszone na pracę zawodowa, nadają jej twórczy charakter. Zgodnie z tym ujęciem twórcza jest nie tylko praca w sferze artystycznej, ale w każdej dziedzinie, począwszy od najprostszych działań do najbardziej złożonych czynności, wykonywanych przez innowatorów, ekonomistów, naukowców itp. (Baraniak, 2004). Konsekwencją twórczego wkładu konstruktora, projektanta czy technologa w proces pracy jest zmiana jej charakteru, która wymusza na pracowniku potrzebę podwyższania kwalifikacji, umożliwiając człowiekowi skuteczne realizowanie nowych zadań zawodowych, wynikających z postępu technicznego i technologicznego, potrzeby przezwyciężania tendencji do rutyny, naśladownictwa, przeciętności oraz przekraczania granic swojej wiedzy i swoich umiejętności i stawiania się podmiotem transgresyjnym (Czerwińska 2009, s. 250-257). Cechy te pozwalają na wyzwalanie człowieka jako podmiotu $\mathrm{z}$ fatalistycznego przekonania o niemożliwości zmiany swojej osobowości i na realizację potrzeby sprostania coraz to nowszym wyzwaniom współczesnego świata, co doskonale ujął w swojej koncepcji pracy kardynał Stefan Wyszyński (Wyszyński 1991, s. 21) o ciągłej potrzebie doskonalenia nie tylko dzieła, ale i jego podmiotu, nawiązującej do wciąż aktualnej tezy Piusa XI. Teza ta wpisuje się w teorię motywacji Abrahama Maslowa, który uważał, że „nigdy nie zrozumiemy ludzkiego życia, jeśli nie weźmiemy pod uwagę jego najważniejszych dążeń. Rozwój, samorealizacja, dążenie do zdrowia, poszukiwanie tożsamości $i$ autonomii, tęsknota za doskonałością, to powszechne dążenie ludzkie" (Maslow 1996, s. 13).

Zgodnie z teoriami autokreacji (Turos 2006) i motywacji (Maslow 1996) praca ujmowana jest w kategoriach wartości, a więc jako sensowna, użyteczna, potrzebna, dokładna, szanowana, dostosowana do możliwości człowieka, rozwijająca, dowartościowująca (Furmanek 2000,2006), umożliwiająca samorealizację (Lewowicki 2003), a także godna człowieka i jego urzeczywistnienia się w procesie pracy, odczuwania podmiotowości (Moskwa 2003). Wymienione cechy pracy łączą się z kształtowanymi postawami w procesie edukacji zawodowej, a więc w procesie kształcenia i wychowania. W połączeniu $\mathrm{z}$ autokreacją rozumianą jako proces uczenia się, twórczego funkcjonowania $w$ obranym, wyuczonym $i$ wykonywanym zawodzie (Nowacki 2006), cechy te nadają procesowi edukacji zawodowej wymiar humanistyczny. Charakterystyczne dla wymiaru humanistycznego jest: 1) wychowanie do sterowania własnym losem poprzez przyswajanie sobie uniwersalnych prawd o życiu ludzkim i umiejętności wyboru wartości do ciągłego doskonalenia swojej osobowości (w aspekcie społecznym i indywidualnym); 2) rozwinięcie motywacji pracy i kształtowania postaw warunkujących właściwy stosunek do pracy, jak i pełną identyfikację z zawodem i ze środowiskiem pracy; 3) wychowanie pracownika chcącego i umiejącego pełnić rolę podmiotu; 4) zespalanie interesów indywidualnych i społecznych, a także często wzajemne ich sobie podporządkowanie; 5) wychowanie pracownika umiejącego żyć i pracować w warunkach gospodarki rynkowej, ryzyka zawodowego itp.; 6) wychowanie członków wspólnoty europejskiej, tj. ludzi, którzy rozumieją sens zjednoczenia Europy oraz potrzebę jego realizowania i umacniania; 7) wychowanie człowieka jako wolnego obywatela państwa demokratycznego, rozumiejącego dokonujące się przeobrażenia w różnych dziedzinach życia i uczestniczącego w nich, znającego swoje prawa i obowiązki oraz czującego się zobowiązanym do ciągłego doskonalenia siebie oraz swego otoczenia (Wiatrowski 2004, s. 7-9). 
Na potrzebę ciągłego doskonalenia się człowieka zwraca uwagę Zygmunt Wiatrowski. Jego zdaniem edukacja zawodowa stwarza szansę holistycznego spojrzenia na proces dążenia do kwalifikacji $i$ kompetencji zawodowych, $w$ kształtowaniu których istotne będą zarówno zbiory wiadomości $i$ umiejętności, jak $i$ zbiory postaw, $w$ tym zawodowych „Wyrażonych stanem mobilności zawodowej, elastyczności, inicjatywności, odpowiedzialności oraz przedsiębiorczości" (Wiatrowski 2004, s. 25-26). Rozpatrywanie tych procesów łącznie, jak twierdzi Ryszard Gerlach, wydaje się uzasadnione, albowiem edukacja szkolna uznawana jest dzisiaj za podstawę dalszego, trwającego do końca życia kształcenia (Gerlach 2003, s. 171), które pokazuje ideę całożyciowego uczenia się, co więcej wyznacza rozumienie edukacji ustawicznej. Zawarta jest ona w większości współczesnych raport oświatowych (Faure 1975; Biała Księga Kształcenia i Doskonalenia 1997; Delors 1998; Mayer 2001).

Rysunek 1. Struktura edukacji zawodowej

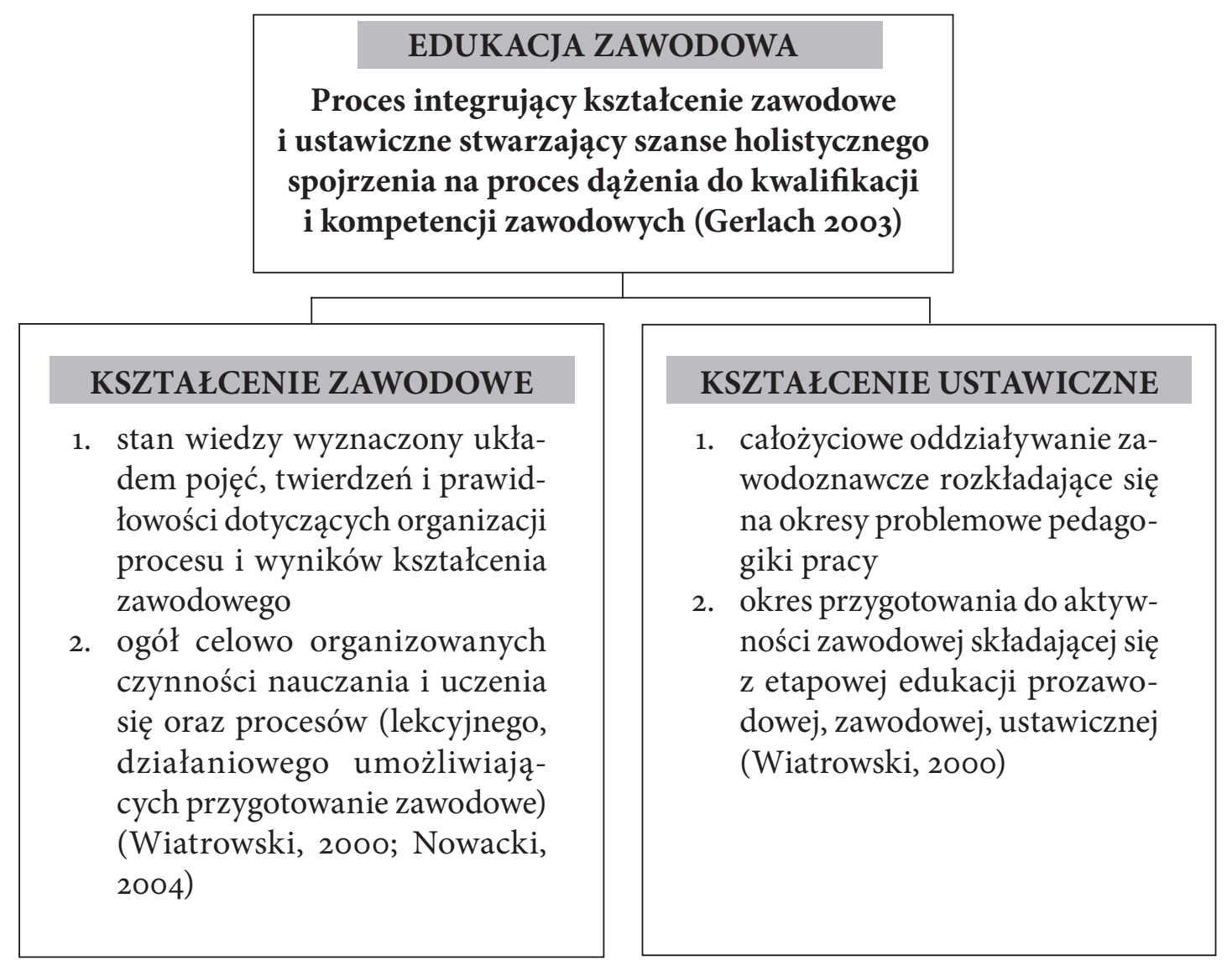

źródło: opracowanie własne

Inny model edukacji zawodowej, oparty również na integracji, ale kształcenia formalnego, nieformalnego i incydentalnego, można wyprowadzić z koncepcji Stefana M. Kwiatkowskiego, co ilustruje poniższy rysunek. 
Rysunek 2. Model edukacji zawodowej w integracji kształcenia formalnego, pozaformalnego i incydentalnego

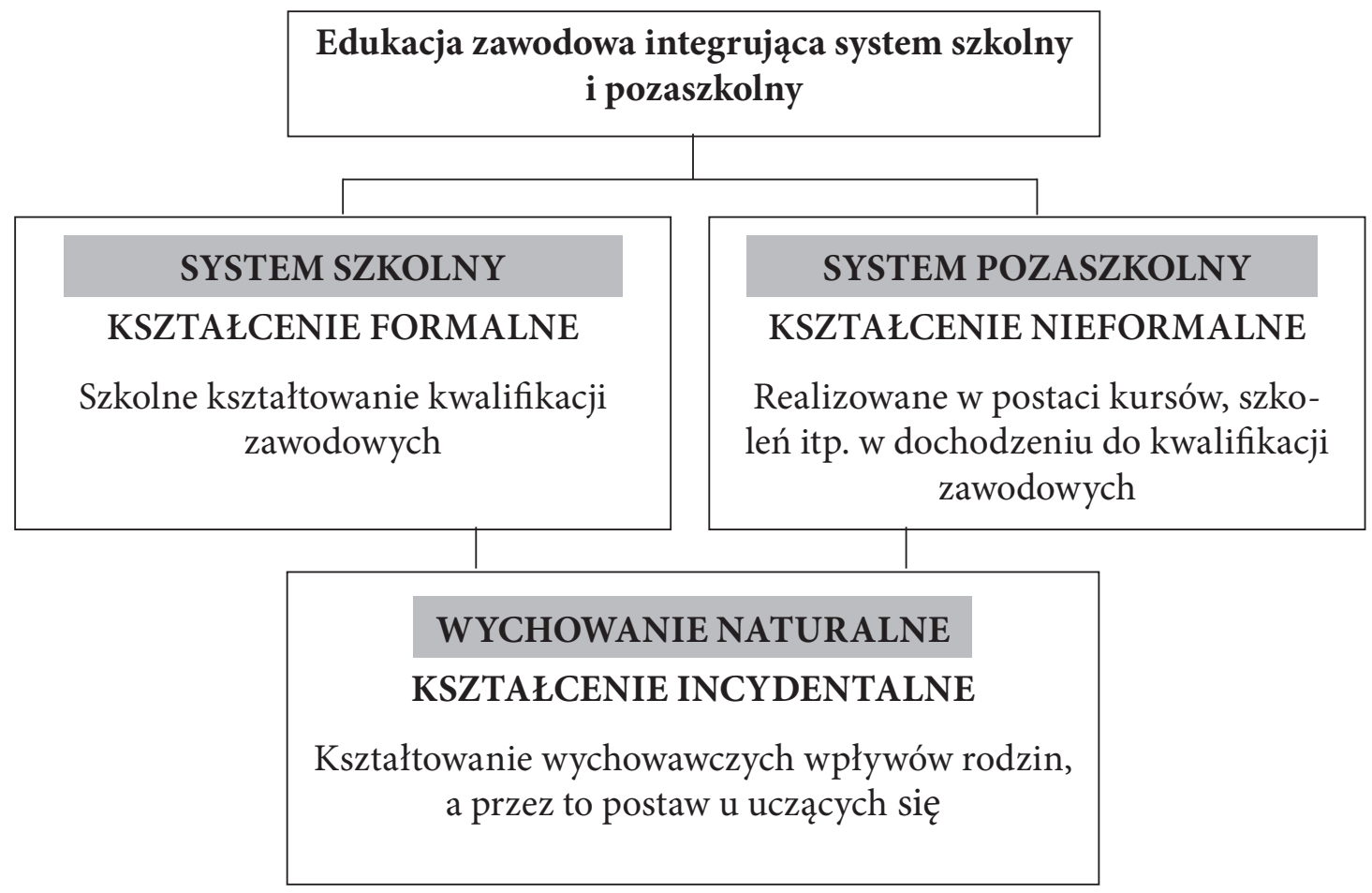

źródło: opracowanie własne

Model edukacji zawodowej integrujący poszczególne fazy kształcenia umożliwia budowanie: otwartego $i$ elastycznego systemu edukacji, rzeczywiste wspieranie aktywności poznawczej i przedsiębiorczości - postaw prowadzących do zwiększania szans na współczesnym rynku pracy (Borkowska 2002). Funkcjonujący w zintegrowanym modelu podmiot edukacji uczestniczy w całokształcie jego procesów, a w myśl aktualnie obowiązującej, tzn. od 1 września 2012 roku, reformy kształcenia zawodowego kształtuje w szkołach zawodowych tylko wybrane kwalifikacje dopełniane w systemie pozaszkolnym, co wpisuje się w model integrowania obszarów kształcenia zawodowego i ustawicznego, czyli edukacji zawodowej. Projektowane w niej elastyczne struktury treściowe powinny znacznie uwzględniać oczekiwania pracodawców w zakresie przygotowania absolwenta do pracy zawodowej, a już pracującemu człowiekowi pozwolić na kształtowanie dalszych umiejętności i kwalifikacji, tym samym umożliwiając mu dopełnianie edukacji w zawodzie (zob. rys. 3), rozpoczętej w systemie szkolnym o dalsze nowe kwalifikacje lub uczenie się na ich podbudowie nowego, pokrewnego zawodu, odpowiadającego aktualnym trendom zatrudnieniowym. To rozwiązanie jest promowane we wdrażanej aktualnie reformie systemu edukacji zawodowej. 
Rysunek 3. Zawód jako zbiór kwalifikacji zawodowych

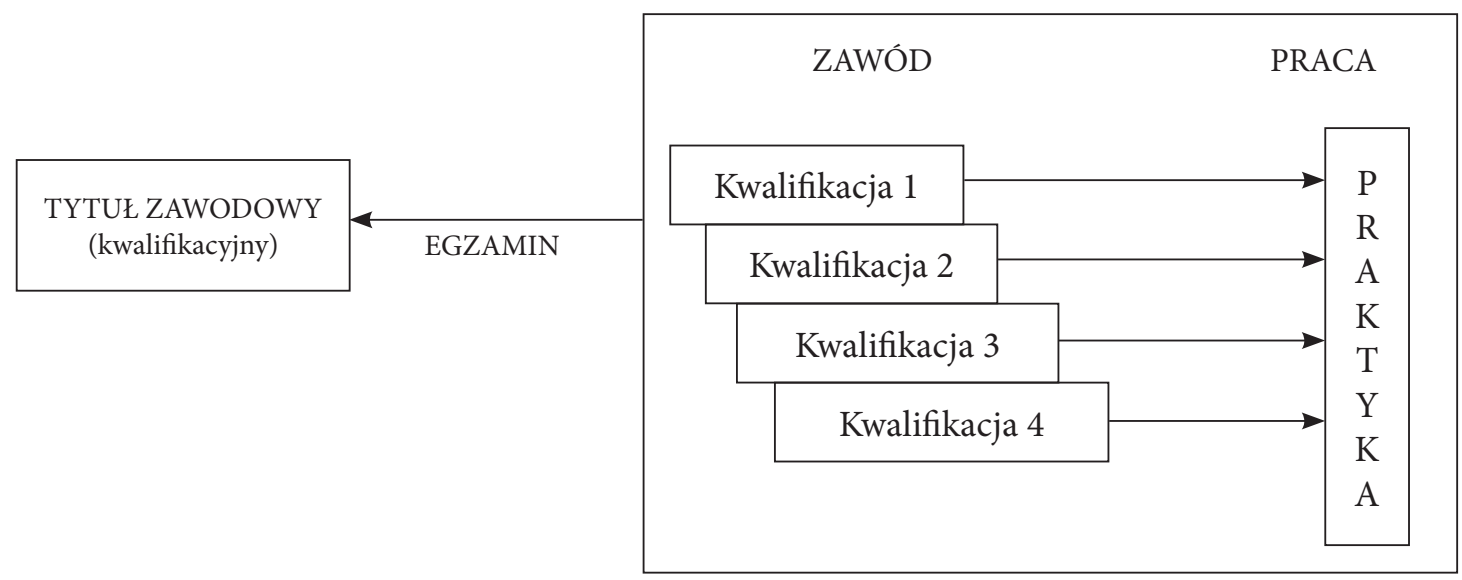

źródło: Szkolnictwo zawodowe 1999

Wspomniana powyżej reforma jest skorelowana z zadaniowym modelem zawodu, upowszechnianym już od 1999 roku i pozwala na wyodrębnienie modułów podstawowych obejmujących zadanie zawodowe wspólne dla wszystkich specjalności oraz moduły specjalnościowo-specjalizacyjne realizowane w czasie kształcenia szkolnego, a następnie kontynuowane podczas pracy zawodowej, dzięki odpowiednim programom szkoleniowych, wpisującym się w edukacyjny wymiar potrzeb procesu pracy, a co za tym idzie programów umożliwiających dochodzenie do coraz wyższych poziomów umiejętności, a wyrażonych zbiorami specyficznych, czyli zmiennych zadań, rozpoczętych w systemie szkolnym, w kontynuowanych w pozaszkolnym. Ilustruje to poniższy rysunek.

Rysunek 4. Model zawodu według założeń klasyfikacji zawodów i specjalności

\begin{tabular}{|l|c|c|l|l|}
\hline \multicolumn{4}{|l|}{ SPECJALNOŚĆ } \\
\hline A & B & C & $\ldots$ & N \\
\hline \multicolumn{4}{|l|}{ moduł podstawowy zawodu } \\
\hline
\end{tabular}

źródło: Rozporządzenie Ministra Pracy i Polityki Społecznej z dnia 12 listopada 2012 r., zmieniające rozporządzenie w sprawie klasyfikacji zawodów i specjalności na potrzeby rynku pracy i zakresu jej stosowania

Obie grupy umiejętności, poprzedzone umiejętnościami wspólnymi dla wszystkich zawodów, powinny być na wciąż uzupełniane umiejętnościami perspektywicznymi, tzw. wyprzedzającymi, wraz z możliwością ich wprowadzenia do kształcenia i uznawania za powszechnie obowiązkowych w ciągu 2-3 lat. Do tego czasu stanowić one powinny dobrowolny wybór osoby uczącej się zawodu, a jednocześnie podstawę do tworzenia dalszych - poza pełnym zakresem przygotowania zawodowego - ofert dokształcania lub doskonalenia zawodowego (Symela 1997, s. 108). Proponowany podział zawodu na różne grupy kwalifikacji opisanych zbiorami wiadomości, umiejętności i postaw legł u podstaw ich opisu efektami poszczególnych bloków kształcenia, objętych treścią podstaw programowych kształcenia w poszczególnych zawodach, w tym stałych i bardziej podatnych na 
zmienność otoczenia, tym samym wpisując się wymagania, trudnego do przewidzenia współczesnego rynku pracy, co przybliża poniższy rozdział opracowania.

\section{Edukacja zawodowa w modelowaniu rynkowego charakteru aktualnie upowszechnianej reformy oświaty}

Zawód i praca stanowi przedmiot zainteresowania zarówno edukacji zawodowej, jak i rynku pracy. Można powiedzieć, iż stanowią swoisty symbiotyczny układ, bowiem tę pierwszą, czyli edukację zawodową interesuje kształcenie w wybranym zawodzie, to jest przygotowanie człowieka do pracy zawodowej, przez co wpisuje się ona w problematykę rynku pracy, który - poza przygotowaniem zawodowym pracownika do pracy, aktualnie oczekuje mentalnościowego, wyrażonego ukształtowanymi przyzwyczajeniami, potrzebą ciągłego doskonalenia umiejętności, wzbogacania doświadczeń w obcowaniu z narzędziami i maszynami, a także innymi instrumentami pracy, w tym współczesnymi „narzędziami” komunikacji bezpośredniej, czyli ludźmi oraz pośredniej, gdzie współczesnym narzędziem staje się komputer wraz z oprzyrządowaniem do internetowej komunikacji odzwierciedlający w postęp cywilizacyjny (Biała Księga, 1997) i niezbędny w rozwoju nowej przydatności zawodowej.

Wreszcie edukacja zawodowa i rynek pracy pokazują, że zawód stwarza styczności społeczne, czyniąc z nas członków pewnych grup, wytwarza autorytety, wzmaga poczucie odpowiedzialności, kształtuje etykę zawodową. To oznacza, że każdy zawód wywiera wpływ na osobowość, charakter i postępowanie człowieka. Stąd płynie wielkie znaczenie wyboru zawodu dla nas samych, a nie tylko dla poziomu życia, a trafność jego wyboru jest szczególnie ważna w aktualnie trudnej sytuacji zatrudnieniowej absolwentów, wyrażonej wysoka ich stopą bezrobocia (Plewka 2013). Zagadnienia te stanowią obszar wciąż mało docenianego poradnictwa zawodowego, które powinno pomoc podmiotom edukacyjnym $\mathrm{w}$ ich orientowaniu na zawód i prace, ale nie można zapomnieć o innych wymiarach edukacji, a mianowicie kształtowania pełni osobowości zawodowej, czyli integracji sfery instrumentalnej, w która wpisują się umiejętności zawodowe, oraz sfery kierunkowej ważnej dla postaw zawodowych, stosunku do pracy, angażowania się w nią itp. One na równi powinny być eksponowane w podejściu pracownika do pracy, co przełoży się na sukcesy zarówno pracowników, jak i pracodawców.

\section{Edukacja zawodowa w założeniach reformy systemu oświaty upowszechniającej prorynkową orientację kształcenia}

Wyrazem dążenia aktualnej reformy edukacji zawodowej jest jej orientowanie na rynek pracy, oczekujący wykwalifikowanej i zaangażowanej w proces pracy kadry, zdolnej do permanentnego rozwoju zawodowego, stosownie do dokonujących się przemian pracy. W owo założenie wpisują się zaprezentowane modele edukacji zawodowej, pokazujące, iż dochodzenie do kwalifikacji i kompetencji zawodowych wymaganych na rynku pracy może odbywać się wieloma drogami, poprzez integrację kształcenia w systemie szkolnym i pozaszkolnym (Gerlach 2003) lub formalnym, nieformalnym i incydentalnym (Kwiatkowski 2006; Baraniak 2008, 2010, 2013), u podstaw których pozostaje potrzeba ciągłego dochodzenia do kwalifikacji zawodowych i ich rozwoju. Aktualna koncepcja 
reformy kształcenia zawodowego Ministra Edukacji Narodowej wpisuje się w powyższe modele edukacji zawodowej, co sprawia, że celem szkolnej nauki zawodowej czyni się nie przygotowanie zawodowe, ale wybrane kwalifikacje zawodowe objęte zakresem podstawy programowej tegoż zawodu (Rozporządzenie MEN w sprawie klasyfikacji zawodów szkolnictwa zawodowego $z$ dn. 23 grudnia 2011 r., poz.7).

Miejscem kształtowania kwalifikacji opisujących dany zawód staje się już nie tylko system szkolny realizowany według obecnej podstawy programowej (Ustawa wprowadzająca zmiany do systemu oświaty oraz niektórych innych ustaw $z$ dn. 19 sierpnia 2011 roku, Dz. U z 2011r., nr 205, poz. 1206), ale i pozaszkolny (Ustawa o promocji zatrudnienia i instytucjach rynku pracy wraz ze zmianami. poz. 415; Ustawa o swobodzie działalności gospodarczej $z d n .2$ lipca 2004 r., poz. 1803). Owo założenie wprowadza elastyczność kształcenia, czyli prawo podmiotu do decydowania o czasie i miejscu dopełniania przygotowania zawodowego kolejnymi kwalifikacjami, skorelowanymi z zadaniami zawodu, wpisującymi się w jego model.

Wreszcie podstawa programowa kształcenia w zawodach wyodrębniła trzy bloki efektów kształcenia, a mianowicie:

1. efektów kształcenia wspólnych dla wszystkich zawodów - na wzór wdrażanego modelu Y charakterystycznego dla kształcenia szerokoprofilowego (Baraniak 2001, s. 1997), następująco opisanych jako:

- BHP - bezpieczeństwa i higieny pracy,

- PDG - podejmowania i prowadzenia działalności,

- JOZ - języka obcego ukierunkowanego zawodowo,

- KPS - kompetencji personalnych i społecznych,

- OMZ - organizacji małych zespołów, wyłącznie nauczanych na poziomie technika.

2. efektów kształcenia wspólnych dla zawodów w ramach obszaru kształcenia. Ich zakres wpisuje się w korelacyjność klasyfikacji zawodów szkolnictwa zawodowego z Polską Klasyfikacją Działalności. Ich wspólne kryterium konstrukcyjne pozwoliło wyodrębnić osiem następujących obszarów kształcenia:

- administracyjno-usługowy,

- budowlany,

- elektryczno-elektroniczny,

- mechaniczny i górniczo-hutniczy,

- rolniczo-leśny z ochroną środowiska,

- turystyczno-gastronomiczny,

- medyczno-społeczny,

- artystyczny.

W obszary te wpisane zostało 200 zawodów opisanych 251 kwalifikacjami w zawodzie, skorelowanymi z efektami kształcenia w kategoriach wiedzy, umiejętności oraz kompetencji społecznych i personalnych, pozwalając na charakterystykę 23 zawodów za pomocą 3 kwalifikacji, 72 zawodów na pomocą 2 kwalifikacji, 98 zawodów jedną kwalifikacją oraz 7 zawodów obszaru artystycznego o innym nie kwalifikacyjnym, specyficznym charakterze kształcenia, dlatego dla nich nie wyodrębniono kwalifikacji w zawodzie.

3. efektów kształcenia właściwych dla zawodu opisanych specyficznymi kwalifikacjami w poszczególnych zawodach, wyznaczając jednocześnie zakres teoretycznego oraz praktycznego w nich kształcenia zawodowego. 
Dopełnieniem prawno-organizacyjnej strony edukacji zawodowej, mającej miejsce zarówno w systemie szkolnym, jak i pozaszkolnym - stanowią egzaminy, których wyniki potwierdzane są świadectwami, dyplomami lub certyfikatami ich kompetencji (Woźniak 2013, s. 184) opisujące poddane ocenie określone, a sprawdzalne efekty uczenia się uzyskane przez uczącego się w ramach jednostki (Załącznik nr 1 do dokumentu Parlamentu UE $z d n$. 09.04.2008).

Efekty kształcenia wpisują się również w reformę szkolnictwa wyższego, które odpowiadając za kształcenie specjalistów realizowane w szkolnictwie wyższym (Rozporządzenie Ministra Pracy i Polityki Społecznej z dnia 27 kwietnia 2010 r. w sprawie klasyfikacji zawodów i specjalności na potrzeb rynku pracy oraz zakresu jej stosowania. poz. 76o), łączy je z kierunkami kształcenia prowadzonymi przez szkoły wyższe (Szkolnictwo wyższe w Polsce 2013) i opisuje również za pomocą wiedzy, umiejętności i kompetencji społecznych będących punktem wyjścia do autonomicznego prawa uczelni do wyodrębniania obszarów kształcenia specjalizacyjnego, adekwatnego do kierunku kształcenia, a wpisującego się w potrzeby rynków pracy - międzynarodowego, w tym światowego i europejskiego oraz krajowego, jak i jego lokalnych potrzeb. Oferta akademickiego kształcenia nieustannie wzrasta, co jest konsekwencją poszukiwania jej zgodności z trendami gospodarczymi i wprowadzania wciąż nowych kierunków kształcenia. Powyżej przywołany dokument Szkolnictwo wyższe w Polsce (2013) - pokazuje tendencje wzrostową kierunków kształcenia, które pogrupowane zostały w trójstopniowym układzie, wyodrębniającym osiem grup:

- kształcenia z podgrupą humanistyczną i pedagogiczną skupiającą 12 kierunków studiów,- nauki humanistyczne i sztuka z dwiema podgrupami: humanistyczną (26 kierunków) i artystyczną (3o kierunków),

- nauki społeczne - gospodarka i prawo z 4 podgrupami: społeczną (1o kierunków), ekonomiczną i administracyjną (22 kierunki), prawną (3 kierunki), dziennikarstwem i informacją (2 kierunki),

- nauka z 3 podgrupami: biologiczną (13 kierunków), fizyczną (24 kierunki) i informatyczną (6 kierunków),

- zdrowie i opieka społeczna z 2 podgrupami: medyczną (15 kierunków) i opieką społeczną (2 kierunki),

- technika, przemysł i budownictwo z 3 podgrupami: inżynieryjno-techniczną ( 32 kierunki), produkcji i przetwórstwa (15 kierunków), architektury i budownictwa (7 kierunków),

- rolnictwo z 2 podgrupami: produkcją rolniczą, leśną i rybołówstwem (6 kierunków), weterynaryjną (1 kierunek),

- usługi z 4 podgrupami: usług dla ludności (6 kierunków), ochrony środowiska (5 kierunków), usług transportowych (2 kierunki), ochrony i bezpieczeństwa (6 kierunków).

Powyższe dane ukazują złożoność obszarów kształcenia na poziomie szkoły wyższej, co wymaga poza wyodrębnieniem ośmiu grup również dwudziestu dwóch podgrup, skupiających w sobie 254 kierunki kształcenia. Na 48 kierunkach prowadzone jest kształcenie na poziomie licencjackim, na 22 kierunkach na poziomie studiów licencjacko-magisterskich, istnieje 39 kierunków na poziomie magisterskim, 24 kierunków kształcących w ramach jednolitych studiów magisterskich, 2 kierunki kształcące na studiów pomostowych, 6 MBA, 44 to kierunki kształcenia podyplomowego oraz 26 - doktorskiego. 
Można zatem powiedzieć, iż podstawę organizacji aktualnej edukacji przygotowującej do pracy, czyli zawodowej w szkołach ponadgimnazjalnych oraz szkołach wyższych, stanowią modele zawodów (szkolnictwo ponadgimnazjalne) lub kierunków (szkolnictwo wyższe) o podobnych liczbach zawodów - $200 \mathrm{w}$ szkolnictwie ponadgimnazjalnym, podzielonym na 8 obszarów kształcenia, a w szkołach wyższych 254 kierunki kształcenia również podzielone na 8 grup, co - w przypadku kontynuacji nauki na studiach przez absolwentów średnich szkół zawodowych - umożliwia kontynuację nauki na zbliżonych kierunkach kształcenia. Wspólną cechę obu poziomów kształcenia stanowią efekty kształcenia opisane wiedzą, umiejętnościami i kompetencjami społecznymi, szczególnie cenionymi przez pracodawców, orientujące edukację zawodową na rynek pracy i potrzebę dalszej kontynuacji nauki w szkolnictwie wyższym oraz systemie pozaszkolnym w celu dopełniania przygotowania zawodowego kolejnymi kwalifikacjami i poszerzania go o nowe umiejętności i kwalifikacje, zwłaszcza w odniesieniu do nauki zawodu szkolnego.

\section{Programy modułowe szansą edukacji zawodowej i jej organizacji}

Modele edukacji zawodowej oraz upowszechniane w nich zawody to przestrzeń kształtowania kwalifikacji. Modele te i zawody integrują kształcenie zawodowe i ustawiczne w systemie szkolnym i pozaszkolnym, dają szansę wdrażania zmodularyzowanych programów edukacji zawodowej, umożliwiających wzajemne przenikanie się obszarów tematycznych, przydatnych w przygotowaniu do kolejnych kwalifikacji zawodowych i ich kształtowania w różnym czasie i na różnym etapie kształcenia, a także kształcenia postaw zawodowych - wyrażanych, współcześnie pożądanym stanem mobilności zawodowej, elastyczności, inicjatywności oraz przedsiębiorczości (Wiatrowski 2004, s. 25-26). Owo przenikanie umożliwia modularyzacja treści, której moduły - jako ruchome elementy programowe - dają możliwość tworzenia różnych ich konfiguracji, realizowanych w różnym czasie, nie tylko w systemie szkolnym kształcenia, w tym zawodowego, ale również i ustawicznego. Idea ta przeniesiona na grunt teorii programów nauczania, umożliwia wzajemne przenikanie się treści i realizowanie ich w różnym czasie, tempie i okresie, umożliwiając elastyczne kształcenie i indywidualne podejście, dostosowane do możliwości każdego ucznia.

Rysunek 5. Procedura wyodrębniania modułów z przedmiotów nauczania

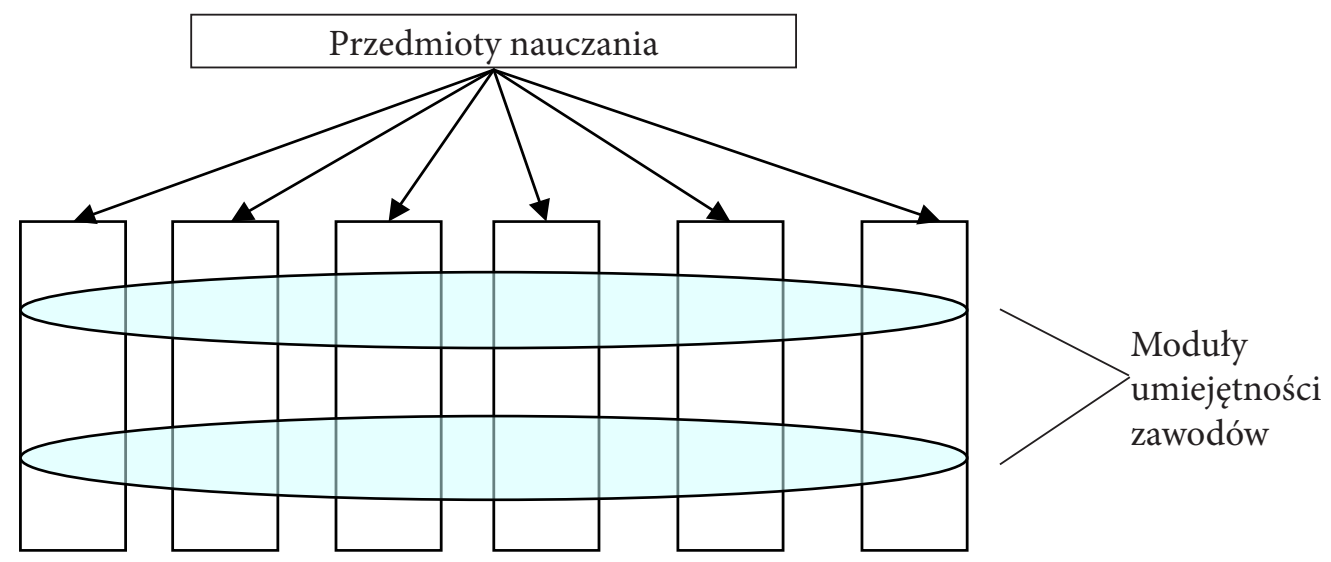

źródło: Chruściel 1995 
Modułową koncepcję edukacji, w tym zawodowej, łączącą w jednolity system etap szkolny z etapem pozaszkolnym, pokazano na kolejnym rysunku poniżej.

Rysunek 6. Integracja edukacji szkolnej i pozaszkolnej w ujęciu modułowym

\begin{tabular}{|c|c|c|c|}
\hline & Moduł 22 & & \\
\hline Moduł 17 & Moduł 18 & Moduł 19 & Moduł 20 \\
\hline Moduł 13 & & Moduł 15 & \\
\hline Moduł 9 & & & \\
\hline
\end{tabular}

program kształcenia

w systemie pozaszkol-

nym -

moduły wybierane

przez uczących się

zależnie od potrzeb np.

charakteru pracy,

oczekiwań praco-

dawców, zainteresowań

edukacja

ustawiczna

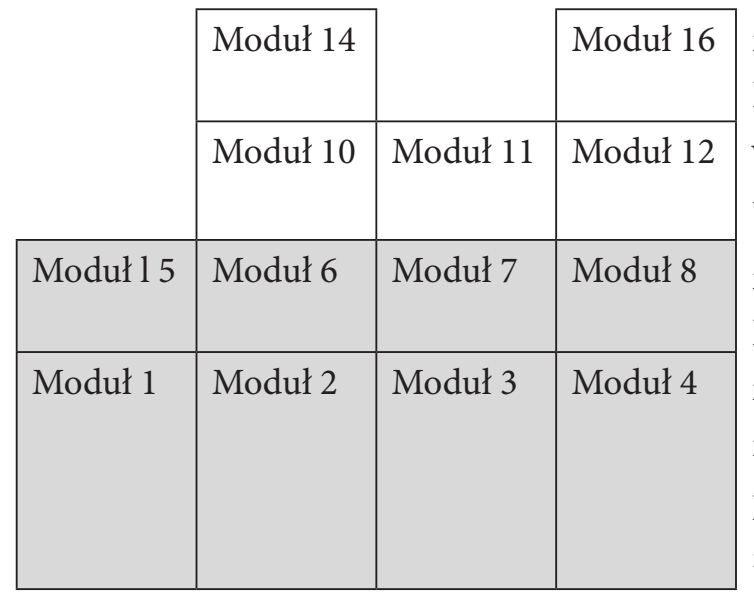

modułowe programy
kształcenia jako moduły

wybierane przez

uczniów

modułowe programy

kształcenia jako

moduły wspólne

realizowane w szkole

podstawowej i gimna-

zjum edukacja

prozawodowa lub

zawodowa

edukacja

przedzawodowa

źródło: Development of Standards in Vocational Education and Training - Specification, Experience, Examples 2000

Powyższy rysunek pokazuje ideę modułowości, a przy tym doskonale wpisuje się w aktualną reformę systemu oświaty z jej propozycją edukacji zawodowej, umożliwiając indywidualne podejście do procesu nauczania i uczenia się. Zawiera ono, obok modułów o charakterze ogólnym i podstawowym, opisujących względnie trwałe (niezmienne) dla zawodu treści, również moduły ilustrujące treści o charakterze specjalnościowo-specjalizacyjnym oraz przyszłościowym będące efektem rozwoju cywilizacyjnego. Te ostatnie kategorie modułów, w zależności od potrzeb rynku pracy oraz stosowanej technologii w danym przedsiębiorstwie, mogą ulegać zmianie w czasie aktywności zawodowej pracownika i powinny stanowić zakres kształcenia ustawicznego realizowanego w formie tradycyjnej kształcenia lub na odległość, potwierdzając zasadność programów edukacji zawodowej, 
integrującej kształcenia zawodowe i ustawiczne, co staje się niezwykle cenne w podziale zawodu na poszczególne kwalifikacje i określanie, które realizuje system szkolny, a które pozaszkolny, czyli konstruowania różnych ścieżek kształcenia. Struktura modułowych programów nauczania wyodrębnia, obok modułu, blok i jednostkę modułową. Ich aplikację do blokowo-modułowego układu treści kształcenia ilustruje zaproponowany przez K. Symelę ogólny schemat struktury i zawartości dokumentacji programowej, a następnie organizacji procesu dydaktyczno-wychowawczego.

Rys. 7. Ogólny schemat struktury i zawartości dokumentacji programowej

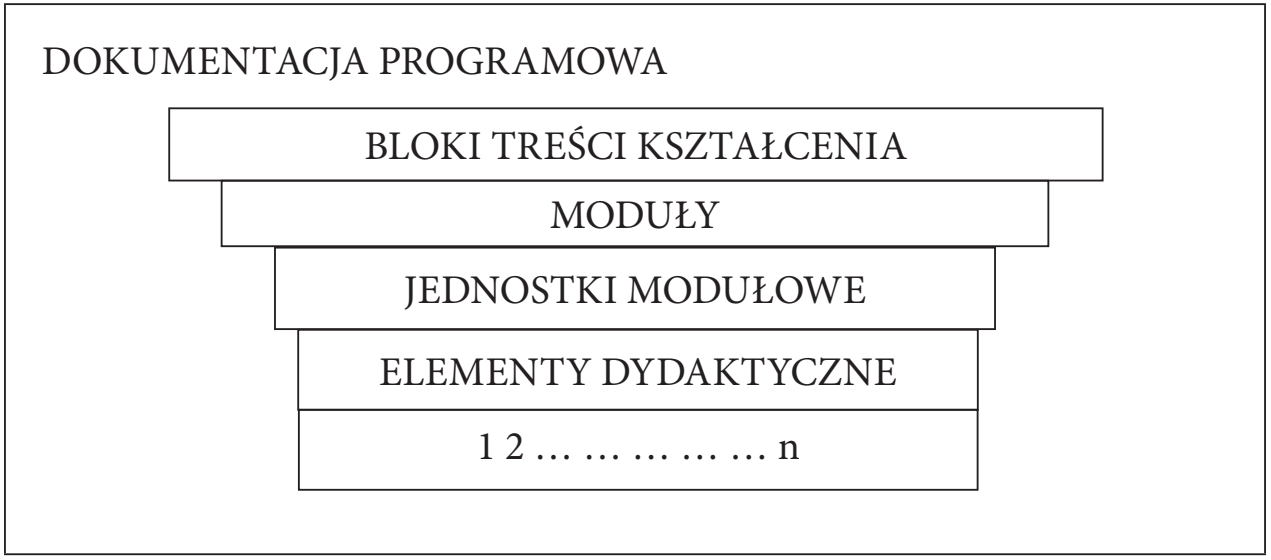

źródło: Symela 1997, s. 109

Poza modułem - kluczowym elementem koncepcji modułowej, pozostaje blok rozumiany jako „skończony element informacyjny, zdeterminowany ogólnym celem kształcenia. Zawiera treści zapewniające jednakowy poziom kształcenia [...] możliwy do wykorzystania we wszystkich formach kształcenia, w tym przekwalifikowywania i podwyższania kwalifikacji” (Symela 1997, s. 112). Jest on wpisany w strukturę modułu, a nim jest „ruchomy dział programu, który umożliwi uczniom osiągnięcie pewnej liczby silnie powiązanych celów poprzez możliwość dobierania jednych, a pomijania innych modułów oraz zmieniania ich kolejności" (Niemierko 2000, s. 9). Blok i moduły stanowią podstawowe elementy konstrukcyjne programu. Sprzyjają kształtowaniu podmiotowych i elastycznych postaw w procesie edukacji (Westby-Gibson 1971, s. 207-208).

Koncepcja programów modułowych doskonale wpisuje się w aktualną koncepcję reformy, obejmującej swym zasięgiem wszelkie kształcenie, w tym szkolne przygotowanie człowieka do pracy zawodowej, począwszy od najniższego poziomu do najwyższego, a także do dalszej edukacji w procesach dokształcania i doskonalenia zawodowego jako ważnych procesach dla szybkiej i elastycznej zmienności pracy, co wymaga kształtowania świadomości uczących się i jego ciągłości, dzięki czemu wzrosną szanse na zatrudnienie absolwentów różnych poziomów kształcenia.

\section{Zakończenie}

Zarysowane tło wsparte kierunkami reform szkolnictwa ponadgimnazjalnego i wyższego, wyznacza potrzebę rynkowego orientowania edukacji, rozumianą jako zbieżność celów 
kształcenia z gospodarczymi, w co starają się wpisywać modele zawodów odpowiadające oczekiwaniom pracodawców, podobnie jak i kształcenie modułowe doskonałe do ilustrowania efektów kształcenia na różnych jego poziomach i w różnych rozwiązaniach organizacyjnych, zapewniając w ten sposób nie tylko elastyczność ścieżek, ale również dostosowywanie oferty edukacyjnej do nieustanie zmieniającego się świata pracy. Należy żywić nadzieje, iż powyższe rozwiązania, wdrażane do praktyki edukacyjnej po ponad dwudziestoletnich badaniach poprawią jej wizerunek, wyrażony lepsza sytuacja absolwentów na rynku pracy, która - obok instrumentalnej sfery wykształcenia - zgodnie z ideą edukacji zawodowej powinna promować również potrzebę kształtowania postaw, poglądów, zainteresowań zawodowych, myślenia koncepcyjnego, innowacyjnego, twórczego, a także stosunku do świata wartości, społeczeństwa, drugiego człowieka, samego siebie, świata kultury i przyrody, czyli pełni człowieczeństwa, tak przydatnego w rozwoju potencjału kadrowego we współczesnych przedsiębiorstwach, gdzie człowiek nie ma być tylko wykonawcą zadań zawodowych, ale dążyć do własnego rozwoju dzięki aktywności, innowacyjnym postawom, upowszechnianym i kreowanym w środowiskach pracy człowieka.

\section{Bibliografia}

Baraniak B. (2008). Edukacja w przygotowaniu człowieka do pracy zawodowej. Warszawa: IBE .

Baraniak B. (2004). Kwalifikacje i kompetencje oczekiwanymi kategoriami współczesnej pracy. „Pedagogika Pracy”, nr 43.

Baraniak B. (2001). Programy kształcenia zawodowego. Teoria - Metodologia - Aplikacje. Warszawa: IBE.

Baraniak B. (2010). Wspótczesna pedagogika pracy z perspektywy edukacji, pracy i badań. Warszawa: UKSW.

Baraniak B. (red.). (1997). Dobór treści kształcenia zawodowego. Warszawa - Radom: IBE - ITiE.

Biała Księga Kształcenia i Doskonalenia. Nauczanie i uczenie się. Na drodze do uczacego się społeczeństwa. (1997). Warszawa - Radom: IBE - ITiE.

Brejnak A. (200o). Rola i miejsce kształcenia modułowego w systemie szkolnym i pozaszkolnym edukacji zawodowej. „Oświatowiec”, nr 2.

Chruściel E., Plumbridge W. (1995). Szkolenie z zastosowaniem umiejętności zawodowych. Warszawa: MPiPS.

Czerwińska M. (2009). Aktywność twórcza w procesie rehabilitacji osób z niepetnosprawnością wzroku - refleksja między terapią a sztuką. W: Dycht M., Marszałek L. (red.). Dylematy (niepełno)sprawności - rozważania na marginesie studiów kulturowo-społecznych. Warszawa: Wydawnictwo UKSW.

Delors J. (1998). Edukacja. Jest w niej ukryty skarb. Warszawa: IBE.

Development of Standards in Vocational Education and Training - Specification, Experience, Examples. (2000). Vol. 2. Torino: European Training Foundation - European Communities.

Doroszewski W. (1975). Słownik poprawnej polszczyzny. Warszawa: PWN.

Encyklopedia Popularna (1997). T. 2. Warszawa: PWN.

Faure E. (1975). Uczyć się aby być. Warszawa: PWN. 
Furmanek W. (200o). Podstawy edukacji technicznej. Rzeszów: URz.

Furmanek W. (2006). Zarys humanistycznej teorii pracy. Warszawa: IBE Fundacja Studiów i Badań Edukacyjnych IBE.

Gaustavi L. (2003). Rozwój modułowego kształcenia i szkolenia zawodowego. Koncepcje i metody. Kształcenie i szkolenie modułowe. Radom: ITiE.

Gerlach R. (2003). Edukacja zawodowa nie tylko dla rynku pracy. W: Gerlach R. (red.). Edukacja wobec rynku pracy. Realia - możliwości - perspektywy. Bydgoszcz: AB.

Gerlach R. (1997). Nauczyciel w pozaszkolnych formach oświaty zawodowej w Polsce. Bydgoszcz: WSP.

Hejnicka-Bezwińska T. (200o). O zmianę w edukacji. Konteksty, zagrożenia, możliwości. Bydgoszcz: AB.

Hejnicka-Bezwińska T. (1989). W poszukiwaniu tożsamości pedagogiki ogólnej. Świadomość teoretyczno-metodologiczna wspótczesnej pedagogiki polskiej (geneza i stan). Bydgoszcz: WSP.

Jan Paweł II. (1996). Laborum exercens. W: Encyklika Ojca Świętego Jana Pawła II. T.2. Kraków: Św. Stanisława B.M. Archidiecezji Krakowskiej.

Jeruszka U. (2006). Kwalifikacje zawodowe. Pogladdy teoretyczne a rzeczywistość. Warszawa: IPiSS.

Kwiatkowski S. M. (2002). Dostosowanie struktury i treści kształcenia zawodowego do potrzeb rynku pracy w kontekście zmian w systemie edukacji. Warszawa: IBE.

Kwiatkowski S. M. (1997). Gospodarcze i społeczne uwarunkowania rozwoju szkolnictwa zawodowego w Polsce. W: Gerlach R. (red.). Dylematy edukacji zawodowej w końcu XX wieku. Bydgoszcz: WSP.

Kwiatkowski S. M. (2001). Kształcenie zawodowe. Dylematy teorii i praktyki. Warszawa: IBE.

Kwiatkowski S.M. (red.) (1994). Kształcenie zawodowe w warunkach gospodarki rynkowej. Warszawa: IBE. Kwiatkowski S. M. (2006). Pedagogika pracy. W: Śliwerski B. (red.). Pedagogika. T. 3. Subdyscypliny wiedzy pedagogicznej. Gdańsk: GWP.

Kwiatkowski S. M. (2000). Prognoza zmian w latach 2000-2010. „Nowa Edukacja Zawodowa”, nr 1.

Lewowicki t. (2003). Humanista $i$ idee humanizmu spetnione w pedagogice pracy. W: Wiatrowski Z., Jeruszka U., Bednarczyk H. (red.). Pedagogika pracy w kontekście integracji europejskiej. Warszawa: WSP TWP.

Łyko Z. (1998). Listy o edukacji. „Forum Oświatowe”, nr 2.

Mayor F. (2001). Przyszłość świata. Warszawa: IBE.

Maslow A. (1996). Motywacja i osobowość. Warszawa: IW PAX.

Moskwa J. (2003). Prorok i polityk. Warszawa: SiK.

Niemierko B. (2000). Od celów operacyjnych przedmiotu szkolnego do ewaluacji programów kształcenia. Brwinów: CEwR.

Nomenklatura zawodów (1966). Warszawa: Komitet Pracy i Płacy.

Nowacki T. (2006). Postawy i wartości. W: Laska E. (red.). Edukacja nauczycieli wobec przemian szkoły. Rzeszów: URz.

Nowacki T. (2006). Przedmowa. W: Turos L. Andragogika pracy. Warszawa: „Żak”.

Nowacki T. (2004). Leksykon pedagogiki pracy. Radom: ITiE.

Nowacki T., Korabiowska-Nowacka K., Baraniak B. (2000). Nowy Słownik Pedagogiki Pracy. Warszawa: WSP TWP. 
Nowacki T. (red.) (1978). Metodologia pedagogiki pracy. Warszawa: IKZ.

Nowacki T. (1982). Pedagogika pracy. W: Laska E. (red.). Pedagogika pracy. Problematyka i przeglad badań. Warszawa: WSiP.

Nowacki T. (1971). Podstawy dydaktyki zawodowej. Warszawa: PWN.

Nowacki T. (1980). Praca i wychowanie. Warszawa: WSiP.

Nowacki T. (1967). Szkice z dziejów kształcenia zawodowego. Warszawa: WSiP.

Ostrowska U. (1998). Doświadczanie wartości edukacyjnych w szkole wyższej. Bydgoszcz: WSP.

Plewka Cz. (2013). Refleksje nad potrzeba powiązania rynku pracy z nauka i edukacja. W: Plewka Cz. (red.). Nauka, edukacja, rynek pracy. Przede wszystkim współdziałanie. Szczecin - Koszalin: Usz - PK - WSzIE.

Rifkin J. (2001). Koniec pracy. Schyłek siły roboczej na świecie i początek ery postronkowej. Wrocław: Wyd. Dolnośląskie. Rozporządzenia Ministra Edukacji Narodowej o zmianie ustawy o systemie oświaty z dn. 19 sierpnia 2011 r., Dz. U. nr 205 Z 2011 r., poz.1206.

Rozporządzenia Ministra Edukacji Narodowej w sprawie klasyfikacji zawodów szkolnictwa zawodowego $z$ dn. 23 grudnia 2011r., Dz. U. nr 2 z 2012 r., poz.7.

Rozporządzenia Ministra Edukacji Narodowej w sprawie podstawy programowej kształcenia w zawodach $z$ dn. 7 lutego 2012 r., Dz. U. nr 34 z 2012 r., poz. 184.

Rozporzadzenie Ministra Pracy i Polityki Społecznej z dnia 12 listopada 2012 r., zmieniające rozporządzenie w sprawie klasyfikacji zawodów i specjalności na potrzeby rynku pracy i zakresu jej stosowania. Dz. U. z dnia 19 listopada 2012 r.

Skrzypczak J. (200o). Kompetencyjne podstawy obywatelskich zachowań dorostych Polaków. „Oświatowiec”, nr 2.

Strategia rozwoju edukacji. (2005). Warszawa: IBE.

Strzelecki Z. (2002). Prognozowanie popytu na prace wedtug kwalifikacji. Warszawa: IPiSS. Suchodolski B. (1965). Kultura. W: Wielka Encyklopedia Powszechna. T. VI. Warszawa: PWM. Symela K. (1997). Przemiany w strukturze programów kształcenia. W: Baraniak B. (red.). Dobór treści kształcenia zawodowego. Warszawa - Radom: IBE - ITiE.

Szkolnictwo wyższe w Polsce (2013), dostępny na: www.gov.pl/92/2013_07 (otwarty 02.05.2014). Szkolnictwo zawodowe. (1999) Zeszyt nr 3. W: Biblioteczka Reformy. Warszawa: MEN.

Śliwerski B. (2003). Edukacja. W: Encyklopedia Pedagogiczna XXI wieku. T. 1. Warszawa. Turos L. (2006). Andragogika pracy. Warszawa.

Ustawa o promocji zatrudnienia i instytucjach rynku pracy wraz ze zmianami. Dz. U. nr 69 z dn. 2008 r., poz. 415.

Ustawa o swobodzie działalności gospodarczej z dn. 2 lipca 2004 r., Dz. U. nr 173 z 2004 r., poz. 1803.

Ustawa o szkolnictwie wyższym z dn. 27 lipca 2005 r., Dz. U. 2005, nr 164, poz. 1365, dostępny na: www.gov.pl/92/2013_07 (otwarty 02.05.2014).

Ustawa z dnia 11 lipca 2014 r. o zmianie ustawy - Prawo o szkolnictwie wyższym oraz niektórych innych ustaw, Dz. U. 2014 poz. 1198, dostępny na: http://isap.sejm.gov.pl/Detai lsServlet?id=WDU20140001198.

Ustawa wprowadzająca zmiany do systemu oświaty oraz niektórych innych ustaw $z$ dn. 19 sierpnia 2011 r., Dz. U z 2011r., nr 205, poz. 1206. 
Wiatrowski Z. (2004). Droga do współczesnego i rozumienia i uznawania kwalifikacji i kompetencji zawodowych. W: Kwiatkowski S. M. (red.). Kwalifikacje zawodowe na współczesnym rynku pracy. Warszawa: IBE.

Wachowski M. (1968). Geneza szkoły. Studium z pedagogiki porównawczej. Opole: WSP.

Wiatrowski Z. (1985). Pedagogika pracy w zarysie. Warszawa: PWN.

Wiatrowski Z. (1996). Podstawy pedagogiki pracy. Bydgoszcz: WSP.

Wiatrowski Z. (2004). Praca w zbiorach wartości pracujących, bezrobotnych i młodzieży szkolnej. Włocławek: WSHE.

Woźniak W. (2013). Idea uczenia się przez całe życie wyznacznikiem zmian $w$ kształceniu zawodowym. W: Plewka Cz. (red.). Nauka, edukacja, rynek pracy. Przede wszystkim współdziałanie. Koszalin - Szczecin: Usz - PK - WSzIE.

Wragg E. C. (1999). Trzy wymiary programu. Warszawa: WSiP.

Wyszyński S. (1957). Duch pracy ludzkiej. Myśli o warunkach pracy. Poznań.

Założenia projektowanych zmian. Kształcenie zawodowe i ustawiczne. (2010). „Informator MEN", Warszawa: MEN.

Załacznik nr 1 do dokumentu Komisji Wspólnoty Europejskiej: Zalecenie Parlamentu Europejskiego i Rady w sprawie ustanowienia europejskiego systemu transferu i akumulacji osiagnięć w kształceniu i szkoleniu zawodowym. (2008). Bruksela: Dz. U. UE L.394, z dn. 09.04.2008.

\title{
OCCUPATIONAL EDUCATION IN EDUCATIONAL REFORM SERVICE ORIENTED ON JOB MARKET
}

\begin{abstract}
Even in our times, occupational education, academically recognised at the turn of the 19th and the 2oth centuries, fits in perfectly with the concept of school reforms in post-secondary schools and higher education. It mostly concerns job market orientation and focus on graduates as well as their chances of employment by inscribing education into employers expectations. Occupational and educational models - also modular - were adapted to educational effects on different levels and organizational solutions and aimed to assure not only flexibility but also adequacy of educational offer to constantly changing job market, what is needed to achieve the goals. It is to be hoped that these solutions used in practise after 20-year research will improve relations between education and job market, expressing it by better situation of graduates.
\end{abstract}

Key words: education, occupational education, job market, educational reform

Barbara Baraniak - doktor habilitowana w zakresie pedagogiki - pedagogiki pracy, profesor Uniwersytetu Kardynała Stefana Wyszyńskiego na Wydziale Nauk Pedagogicznych; autorka ponad 230 publikacji. Na uwagę zasługują m.in. Wspótczesna pedagogika pracy z perspektywy edukacji, pracy i badań (2010, 2013), Metody badania pracy (2009), Edukacja w przygotowaniu człowieka do pracy zawodowej (2008). Adres do korespondencji: Wydział Nauk Pedagogicznych, ul. Wóycickiego 1/3, 01-938 Warszawa. Adres e-mail: b.baraniak@uksw.edu.pl 